This item was submitted to Loughborough's Research Repository by the author.

Items in Figshare are protected by copyright, with all rights reserved, unless otherwise indicated.

\title{
Managing surveillance? The impact of biometric residence permits on UK migrants
}

PLEASE CITE THE PUBLISHED VERSION

http://www.tandfonline.com/doi/abs/10.1080/1369183X.2011.623624

PUBLISHER

(C) Taylor and Francis

VERSION

AM (Accepted Manuscript)

LICENCE

CC BY-NC-ND 4.0

REPOSITORY RECORD

Warren, Adam P., and Elizabeth Mavroudi. 2019. "Managing Surveillance? the Impact of Biometric Residence Permits on UK Migrants". figshare. https://hdl.handle.net/2134/9047. 
This item was submitted to Loughborough's Institutional Repository (https://dspace.lboro.ac.uk/) by the author and is made available under the following Creative Commons Licence conditions.

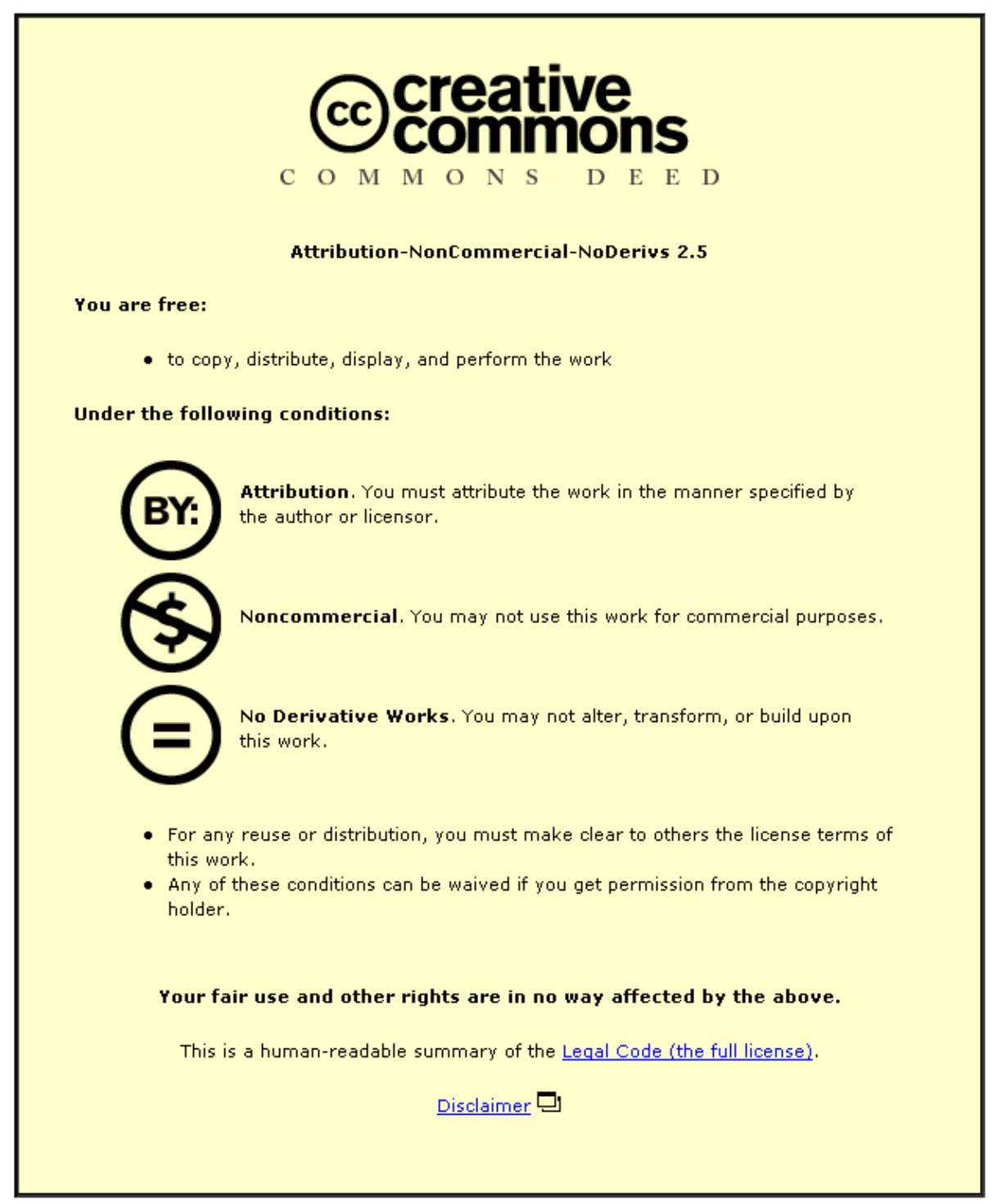

For the full text of this licence, please go to: http://creativecommons.org/licenses/by-nc-nd/2.5/ 


\title{
Managing Surveillance? The Impact of Biometric Residence Permits on UK Immigrants
}

\author{
Adam Warren and Elizabeth Mavroudi
}

On 27 May 2010, the newly formed UK Coalition government announced the cancellation of national identity cards for UK citizens. Yet, foreign nationals remain subject to a separate biometric identity card scheme-renamed 'Biometric Residence Permits' (BRPs)—currently being rolled out to various categories of migrant. To date, over 300,000 such cards have been issued to various foreignnational groups, including international students, visiting scholars, entrepreneurs, investors and domestic workers. Although research has been conducted on UK immigration policy, there has been little investigation into how foreign nationals view, experience and negotiate BRPs. In this paper, we draw on our own empirical work to examine the impact of BRPs on migrants. From March to December 2010, interviews and participative research were conducted with the Home Office, the UK Border Agency, advocacy and civil society groups, Higher Education Institutions and individual migrants. We consider the extent to which this scheme acts as a means of exercising surveillance and control over foreign nationals, and the ability of these migrants to negotiate around such constraints.

Keywords: Non-EEA Migration; Surveillance; Biometric Residence Permits; Active Agency; Identity; United Kingdom

\section{Introduction}

On 21 December 2010, the Identity Documents Bill-the first legislative measure of the UK Conservative-Liberal Democrat Coalition government formed following the May 2010 general election-received Royal Assent. This legalised the abolition of the UK national identity card and its supporting National Identity Register. A flagship policy under the previous Labour administration, the national identity card scheme for UK citizens had been beset with difficulties over the course of the previous decade, with confusion as to its purpose, and concerns being raised over its cost, implications for civil liberties and the security of the biometric personal data collected. By the time of the May 2010 general election, only the Labour Party continued to support the principle of a national identity card for UK citizens, with both Conservative Party and Liberal Democrat Party manifestos containing explicit pledges to scrap the scheme (Conservative Party

Adam Warren and Elizabeth Mavroudi are respectively Research Associate and Lecturer in Geography at the University of Loughborough. Correspondence to: Dr A. Warren/Dr E. Mavroudi, Dept of Geography, University of Loughborough, Loughborough LE11 3TU. E-mails: a.p.warren@lboro.ac.uk; e.mavroudi@lboro.ac.uk. 
2010; Liberal Democrat Party 2010). Nevertheless, an identity card for foreign nationals-originally launched in November 2008, and currently known as the Biometric Residence Permit (BRP)—was retained. The BRP is at present being rolled out in stages, with the intention of achieving coverage of all new applicants by 2012 (Home Office 2010).

The implications of the shelved UK national identity card scheme for migrants and mobile populations have been considered by a number of scholars, focusing on aspects of governance (Zureik and Hindle 2004), politics (Whitley and Hosein 2008; Whitley et al. 2007) and personal identity management (Beynon-Davies 2006, 2007, 2010; Joinson et al. 2006). A strong theme running through the academic discourse on this topic has been the political imperative of being seen to 'manage' migration. For example, Geddes (2006) has considered how concerns about irregular, transnational migration feed into the debate on the creation of a national identity card as a means of improving national security. Lyon contended that national identity cards 'encourage[d] less inclusive notions of citizenship', facilitating the sorting of 'desirable' and 'undesirable' mobilities based on the criteria of 'identity management' (2007a: 111). Finally, Flynn considered biometric identity cards to be an additional management tool, allowing the migrant 'to be tracked through all the stages of his/her residence in the UK, and for discipline to be inflicted on those who infringe the rules' (2005: 485). In this paper, we build on this broad research from across the social and political sciences and contribute to theoretical understandings on the interrelationships between surveillance, security, identity and managed migration. We suggest that these operations require a more nuanced understanding of how migrants actively manage security-driven surveillance within their everyday lives and how surveillance impacts upon migrant identities and belonging. Using a case study on the roll-out of the BRP for non-EEA foreign nationals in the $\mathrm{UK}^{1}{ }^{1}$ we argue that the card has the potential to create both difficulties and opportunities for migrants and that greater attention needs to be paid to differing perceptions and negotiations of such surveillance tactics.

We begin by reviewing the theoretical and empirical work on UK immigration policy and identity cards, biometrics and surveillance. We comment on the extent to which the shifting discourses on migration have influenced the debate on the introduction of an identity card for non-EEA nationals, in particular for migrants perceived by the UK government to be 'skilled' or 'highly skilled' (see Table 1), and the potential impact this document may have on their lives in the UK. We then discuss our fieldwork: a series of interviews and participative research involving individuals from the Home Office, the UK Border Agency (UKBA), migrants' rights organisations, a Higher Education Institution (HEI) and 20 foreign-national Higher-Education (HE) postgraduate students and staff. The findings from our research are highlighted, with attention given to the perspectives of non-EEA nationals, and conclusions are then drawn.

\section{UK Immigration Policy and Surveillance: Managing Entry and Identity}


Since the late 1990s, the UK, like many other Western countries, has followed a policy of 'managed migration' in an attempt to attract skilled migrants who could be of economic use to the country (Spencer 2003). This has been combined with increased border controls, the restriction of low-skilled migration and asylumseekers, and the promotion of greater social cohesion and integration. Despite being contested (Finch and Mulley 2009; Flynn 2005; Robinson 2010), this approach continues to guide UK immigration policy. Two policy changes are particularly relevant to this discussion: the rolling out of the Points-Based System (PBS) and the introduction of BRPs. Both were enshrined in national legislation via the UK Borders Act 2007.

The PBS was phased in between 2008 and 2010, with the aim of ensuring that 'the Government will be able to both keep out migrants who will not benefit the UK and actively favour those who will' (Home Office 2008: 18). It replaced the 80plus categories of work permits with five 'tiers', each of which is associated with certain skills, categories and 'points' (Table 1). It is a system that is largely seen to be based on other Western visa administration arrangements, such as those in place in Australia and Canada (Bach 2010; Doomernik et al. 2009; House of Commons 2009). The BRPs have been legitimised through the EU regulatory framework, with the UK opting in to EC Regulation 1030/2002, which lay down a uniform format for residence permits for third-country nationals. This was amended by EC Regulation 380/2008, aimed at upgrading the security features to contain certain biometric data-in this case, fingerprints and a digital facial image (Home Office 2010).

\section{[TABLE 1 NEAR HERE]}

Scholars have contended that this scheme is symptomatic of 'Fortress Europe', encouraging and supporting mobility within the continent, whilst increasingly restricting access to applicants from outside the EEA. In this thesis, the EEA has 'come to resemble a gated community in which the bio-political control and management of immigration is, to a large extent, the product of fear' (Van Houtum and Pijpers 2007: 291). The EEA/non-EEA dichotomy which has been created stresses that those from outside the EEA are deemed not only to be unwanted but also to be potentially risky, a security threat that needs controlling and monitoring (Delanty 2008). As a consequence, non-EEA migrants have been subject to greater restriction and surveillance. Within this conceptual framework, the BRP can be seen as an attempt to categorise and 'sort' non-EEA migrants, creating new geographies and politics of difference, as these groups have to contend with additional identity documents which then become part of their everyday lives, practices and identities whilst resident in the UK (Lyon 2007a).

We argue that it is important to understand how migrants themselves perceive and respond to surveillance and the extent to which it impacts upon their bodies, everyday lives, identities and practices. The emergence of biometric identity cards has arguably increased the need for research in this area. Indeed, Lyon, when discussing biometric ID cards, stated that it was '... unclear at present what the apparently large leap forward in surveillance power will mean [...] and little 
social science research has been done on their impact' (2007b: 166). Nevertheless, a number of studies have drawn attention to the complex ways in which migrants negotiate identity and belonging in the UK, particularly in relation to diasporic and transnational networks (Burdsey 2006; Hussain and Bagguley 2005; Nagel 2002). Scholars have also demonstrated how feelings of alienation and marginalisation due to perceptions of difference and xenophobia may also result in migrants and ethnic minorities finding it more difficult to 'belong' within British society (Abbas 2007; Phillips 2006, 2010). More recently, migration has been conceptualised as an embodied process, with the scale of analysis on the migrant rather than on migration flows (Dunn 2010). In this construction, BRPs can be seen as expanding the geographies of bodily surveillance; the cards form part of everyday lives and spaces, whether they are carried around or not. Through these processes, the Home Office continues to control non-EEA foreign nationals long after they have passed through official immigration control. ${ }^{2}$ This surveillance occurs both within and beyond states, as foreign nationals use BRPs not only to provide evidence of permission to live and work in the UK, but also when they travel in other EEA states.

In this paper, we focus on non-EEA postgraduate students and staff, investigating the extent to which their experiences inform the wider debate on the borders of Europe and the policies that discriminate on the basis of citizenship, security and risk. By concentrating on these groups of highly skilled and educated people, we wish to stress the need to consider how immigration policies and documents such as the BRP impact upon individuals often perceived to be highly mobile. Whilst these groups have been the subject of previous scholarly work (Beaverstock 2005; Koser and Salt 1997; Ley 2004, 2010), we argue that there is a need to examine some assumptions made about skilled migrants, in particular, the assertion that they find it easier to make choices and changes in their lives (Favell et al. 2009; Hawthorne 2008; Koser and Salt 1997). In comparison to lowskilled migrants and asylum-seekers, educated HE students and staff may be better placed to deal with immigration policy requirements and find it easier to enter, work and/or study in the UK. However, there is still a need to examine in detail the ways in which skilled migrants deal with perceptions of difference, and the surveillance to which they are subject. In this respect, it is important to distinguish between HE students and staff. Whilst both groups may be more mobile than other migrants and not generally be expected to settle in the country of destination (Findlay et al. 2010; Kim 2007), we did encounter HE staff during our fieldwork who had either been granted indefinite leave to remain in the UK, or intended to apply for indefinite leave in the near future. In a similar vein, the poststudy work visa has also allowed international students to stay on after their studies to work and potentially settle in the UK, although it should be noted that this type of visa is currently under review (UKBA 2010a).

\section{Methods}

Data for this paper were gathered via desk research and fieldwork. Initial desk research reviewed the literature relating to the relevant international and national 
regulations, official guidance on the national identity card scheme, and related papers produced by academic researchers, advocacy groups, civil society organisations and service providers (for example, educational institutes). This has been supplemented by documentation gathered during the fieldwork phase. Empirical research was conducted from March to December 2010, and took the form of semi-structured interviews (each lasting approximately one hour) and participative research. These methods enabled us to engage in detailed discussions with a variety of organisations and to experience aspects of the biometric enrolment procedure. We initially approached the Home Office, the UK Border Agency (UKBA) ${ }^{3}$ and a national migration advocacy group. Further participants were identified either by their job title or via recommendation from earlier contacts. Interviews were conducted with managers, advisors and employees at a regional migrant advocacy group based in the Midlands, a national employer's organisation and an HE institution, also located in the Midlands. In addition, in-depth interviews were conducted with 20 foreign nationals-international postgraduate students and non-EEA HE staff employed at UK universities, working in the fields of science, engineering, business, information technology and social science. In almost all instances, the meetings began with an overview of the process involved in acquiring the BRP, followed by comments on the card itself, and its perceived utility. The interviews concluded with participants being asked to locate the scheme within their perceptions of the UK as a host country, allowing the foreign nationals to consider their identity and sense of belonging within the UK. Finally, we were given 'walk-through' tours of two UKBA Public Enquiry Offices (PEOs), observing and experiencing the biometric enrolment process. Our fieldwork was conducted during a period of flux, commencing when identity cards were beginning to be rolled out across various migrant categories, as well as being piloted on a voluntary basis to selected UK citizens. It continued through the 2010 general election campaign and beyond, to the enactment of the Identity Documents Bill in December 2010.

\section{The Biometric Residence Permit Enrolment Process}

In November 2008, the first national identity cards for over half a century were issued by the UK government to foreign nationals. The BRPs-known at the time as 'Identity Cards for Foreign Nationals' (ICFNs)—were originally envisaged as part of a national identity card scheme that would also include UK citizens. They involved non-EEA foreign nationals 'enrolling' their facial images and fingerprints at a UKBA biometric enrolment centre (for postal applications only), a UKBA PEO (for postal or premium applications) or at a limited number of approved post offices. Applications could be made by post or in person (known as premium applications). The costs of applying for the BRP were included as part of the visa application fees that comprise the PBS, and varied according to the type and method of application. For example, at the time of writing, an individual applying to study in the UK would have payed (under Tier 4) $£ 357$ if applying by post and $£ 628$ if applying in person. ${ }^{4}$ A skilled worker with a job offer from a UK-based employer (Tier 2) would have paid $£ 475$ if applying by post and $£ 730$ if applying 
in person. Postal applications took four to eight weeks; ${ }^{5}$ premium submissions were processed either on the same day or within 24 hours. Migrants in most PBS categories were charged less if they were applying from outside the UK.

In order to enrol their biometric information, the migrant either booked an appointment at a UKBA biometric enrolment centre or a UKBA PEO. Alternatively, he or she could report to an approved post office without prior arrangement (and pay an additional fee). Children under the age of 16 needed in all instances to be accompanied by a responsible adult. Prior to data capture, the applicant was asked if he or she had used any other names in previous UK immigration/visa applications and whether he or she had given their fingerprints as part of previous applications, either in the UK or abroad. The applicant would then have a digital photograph taken and, if aged six years and older, would have had images taken of ten fingerprints. ${ }^{6}$ Following data capture, the applicant would have been required to wait whilst a number of checks were undertaken. For example, the biometric data would be verified against previous data given by the foreign national. Moreover, it would be checked against police and immigration databases. At a large PEO, this process could take between 30 minutes and three hours. Once the checks had been made, the applicant would be informed and either allowed to leave (if he or she had submitted a postal application) or would be referred to a caseworker (if it was a premium application). In a 'tiny minority' of cases, where irregularities were noticed, the applicant may then have been referred to an 'arrest team'. ${ }^{7}$ The enrolment information-for both postal and premium applications-would then be transferred to a casework team, which would make a decision on the application. If the permit was granted, the applicant's biometric data were sent in encrypted form to the Driver and Vehicle Licensing Agency (DVLA), ${ }^{8}$ which also issues driving-licence cards to UK drivers. Here the data would be 'decrypted [...] verified and then run for card production'. The card would be received by the applicant, via secure delivery, within 10 working days of the date of the decision letter. By November 2010, in excess of 300,000 BRPs had been issued to non-EEA migrants since their initial roll-out on 25 November 2008 (House of Lords 2010).

BRPs have been phased in across a number of foreign-national classifications. Currently, individuals need to apply for a BRP if they are in the UK and wish to extend their permission to stay in one of the immigration categories listed in Table 2. Since 6 April 2011, any migrant extending their stay in the UK or wishing to stay for more than six months needs to apply for a biometric residence permit as part of their immigration application (UCAS 2010). By 2015, 90 per cent of all immigrant categories will be covered by the scheme (Casciani 2008).

[TABLE 2 NEAR HERE]

\section{Managing Surveillance? Foreign Nationals and the Biometric Residence Permit}

In this section, we have arranged our findings in order to capture interviewee perspectives of (i) the process involved in acquiring the BRP, and (ii) the BRP 
itself. In terms of the latter, we were particularly interested in the card's utility and the extent to which the requirement to apply for a BRP affected foreign-national perceptions of the UK as a host country. Our empirical work identified a number of trends. The foreign-national interviewees were generally accepting of the principle of restricted immigration policies and their associated visas issued in the form of a permit or identity card. In addition, they recognised the benefits of a universal card that could be produced in exchange for access services such as banking, general practitioners and car hire. Nevertheless, the application for, and subsequent use of, the card often involved protracted negotiations with a number of actors within the UK, including retailers, university administrators, government agencies, the police and car-hire companies. In the process, there was the potential for tension and constructions of difference. Moreover, the burdensome nature of the application procedure was remarked on by non-EEA migrants and $\mathrm{HE}$ administrators, with the detailed, frequently changing procedures being perceived as potentially deterring highly qualified students and researchers from working in the UK. Finally, a number of interviewees (international students, nonEEA HE staff and the advocacy groups) expressed concern that the restriction of the permits to foreign (non-EEA) nationals could result in discriminatory treatment.

\section{Obtaining a BRP: An Efficient Process?}

The formal process of acquiring a BRP has been described above. However, it is important to examine participants' views of the process and the BRP as a form of surveillance, during which personal biometric information has to be provided. Within our sample, the majority of interviewees believed the procedure to be too long and too costly, and subject to change at very short notice. Representatives of the HE sector were particularly critical of the roll-out of the BRP, arguing that it had added considerably to the workload of those tasked with advising students.

Numerous examples were given (often in great detail) of instances where clerical errors, or seemingly excessive procedural requirements, had resulted in problems for foreign-national students and staff alike. For instance, the permits were often issued in the wrong name, with incorrect spellings or errors in the sponsoring organisation's licence number. Student bank statements had been rejected, in spite of showing that finances were in good order, for not meeting rigid pro-forma requirements. Moreover, as the applicant's passport is no longer endorsed, the BRP application process had caused difficulties for HEls in tracking students' residence history, i.e. the HEI could no longer prove how long the student had been in UK or the length of time they had been resident with permission. This, in turn, created additional work for HE administrators in verifying the eligibility of applicants applying for extensions.

Furthermore, the students and staff we interviewed-whilst generally in favour of BRPs, or at least supportive of the rationale underpinning the schemeexpressed unhappiness at aspects of the visa application process involved, which is a necessary prerequisite to obtaining a BRP. The visa application forms were perceived to be over-long and difficult to comprehend. Students submitting 
via the postal route, in particular, faced a considerable period without a passport once their application had been despatched. One interviewee, a PhD student requiring a six-month visa extension, was advised that a wait of 23 weeks was likely before the passport or BRP would be received. Whilst this may have been exceptional, it was clear that applicants were facing long periods where they would be unable to leave the UK. The affected interviewees perceived this to be detrimental to their professional development-for instance, in limiting opportunities to network or to present papers at high-profile conferences overseas. They also queried the need to have to send off their passport-a source of considerable concern for some, as they were unclear as to when they would get it back. Others were frustrated at having to devote a considerable amount of time, and expense, to repeatedly enrolling biometrics 'in Beijing, in Sheffield and maybe [again] six months later' (interview with an HEl advisor). Foreign-national staff were more likely to be pragmatic about the actual process of getting a BRP although they felt the procedure should be as simple and cheap as possible. Non-EEA students, however, were less happy about BRP and were often particularly concerned about the cost of extending their visa (which, prior to 2003, was free) and the delays processing visa renewals. ${ }^{9}$ They also felt that the drawn-out visa application process and complex way in which the BRP was issued sent a negative message to would-be applicants.

Moreover the incremental introduction of the scheme-with certain groups required to apply for BRPs, but others not-caused some confusion. The two-part process of obtaining a BRP-with the biometric data being enrolled at one location, and the actual card being issued from another-proved problematic and time-consuming for migrants. In addition, there had been a lack of biometric enrolment capacity at the start of the roll-out of the BRP. One HEl advisor reported that:

[P]art of the problem was that they didn't have enough biometric centres. For example, they didn't start off having one in Northern Ireland so if you're a student in $\mathrm{NI}$ then you're supposed to traipse off to Glasgow and you know that's quite an undertaking and even within mainland Great Britain, you know if you're in Plymouth or Exeter, I think the nearest place is Cardiff, um, there were huge capacity issues.

However, those employed at the biometric enrolment centres were confident that they were working effectively and coping well with demand; they did not believe that there were delays. This may suggest that initial problems, at least at the front-line, had been resolved. This position appears to be corroborated by some foreign-national interviewees, despite the issues that were raised above. They stressed that enrolment staff were often friendly and professional and answered their questions satisfactorily. There were, however, instances where confusion existed or where migrants thought the whole procedure to be rigid and at times intimidating. In particular, students expressed concern at the time and cost involved in travelling to a biometric enrolment centre for a specific time, especially when their appointment was not at the nearest outlet. Yet, whilst the biometric enrolment process was perceived as a potential barrier to mobility, 
resulting in greater expense and some aggravation for non-EEA migrants, most interviewees were, in principle, content to provide biometric data.

\section{The BRP, Identity and Everyday Life}

Most foreign nationals interviewed had a positive view of the UK, welcoming the opportunity to study or develop their career within the UK's well-established HE sector. Moreover, they felt that they had a responsibility to do what they could to belong both to their universities and to the areas in which they lived. Indeed, a number did believe that possessing a BRP could assist them in this process. This suggests that foreign nationals do not necessarily perceive and experience surveillance in negative ways. Many interviewees carried the physical cards with them on a daily basis as a form of identification. However, they did not appear to be actively used. Most commonly, the card was produced by the migrant at the $\mathrm{HEI}$ or at international airports as proof of legal right of residency. Indeed, the majority of foreign nationals interviewed viewed the permit as beneficial, 'a formal thing [...] to open an account at the bank [and] apply for loan [hire] cars' (student, $\mathrm{HEI}$ ). Yet, cardholders expressed concern about losing the document or not having it recognised at retail outlets or when they travelled abroad. ${ }^{10}$ However, other interviewees, such as a South Asian IT consultant employed at an HEI, were attracted by the portability of the card:

\footnotetext{
[A]nywhere that I need to show proof to show I'm a legal immigrant and I have rights to stay or work here, I guess if the ID card suffices as proof for those things then it's better, I don't have to carry my passport etc., and [that] makes life easier I would say.
}

However, some participants were unclear about the information displayed on the card. One HEl employee stated that he did not understand why the phrase 'restricted work' was present on his card, and expressed uncertainty as to its use to a potential employer as an identifying document. Another interviewee, a student, showed us her card, which had the words 'work 20 hours maximum in term time' marked on it. In this instance, it was information intended to make the cardholder's entitlement to work very clear to potential employers.

In addition, our research also revealed that foreign nationals did not perceive the BRP to be of great assistance as they adapted to life and negotiated belonging in the UK. ${ }^{11}$ It could be argued that this is due to the BRP being seen as a material and symbolic reminder of difference. One interviewee, a staff member at a $\mathrm{HEl}$, remarked:

I'm used to the idea of the ID card. It's something, I realise that people look [at] you differently when you're on the borders of immigration.

Many interviewees, especially those from emerging economies such as India, China and Argentina, were pragmatic-as foreign nationals within the UK-about this sense of difference. Others-particularly from countries such as Australiafound it more problematic. For example, an Australian HEl employee stated: 


\begin{abstract}
Why should it only be non-EEA people who get singled out? The form itself didn't make me feel bad but I thought 'Why am I having these forms?'. I think it's because I don't class myself as being different from anyone next to me-it more or less pointed out 'You're different, you're not from here'. I'm also very aware, I make a joke of it sometimes ... but I say 'If I get arrested for this, I'll get deported'. You do realise this and it's always at the back of my mind. I feel the same as people here but I am in a different position.
\end{abstract}

This may suggest that perceptions of difference were related to nationality, race and ethnicity. Indeed, an employee of the UKBA commented that those who raised the most queries and were the most concerned about the BRP were from 'Anglo-Saxon' countries such as the USA and Australia. Nevertheless, a wider range of interviewees voiced concerns about an identity card being required solely for foreign nationals. One interviewee (an HEl academic from a South American country) stated:

[I]f you are singling people out, then I wouldn't like this because even though ethnically I may squeeze through, I have an accent and it's pretty obvious that I am a foreigner and I would be concerned if I had to carry a particular ID that singled me out as a foreigner.

This fear of being 'singled out' resonated with anecdotal evidence received by interviewees employed at migration advocacy groups. They expressed concerns that, with immigration controls being 'out-sourced' to public service-providers (for example, NHS Primary Care Trusts, local authorities) and to employers, 'legitimate' migrants were experiencing discrimination due to employer fears of being penalised for hiring illegal immigrants.

In terms of a pay-off from a discrimination case brought in the employment tribunal versus a civil penalty fine, you're better off taking the chance to discriminate-in cash terms... (Director, national migration advocacy group).

At the same time, the advocacy groups believed the complexity of the new legislation and the risk of heavier fines involved would be used by lessscrupulous employers as a reason for not hiring migrants per se, or individuals from certain ethnic groups, regardless of citizenship. Although the foreignnational interviewees in our study were not generally affected by employer discrimination by virtue of being students or skilled workers, some expressed disquiet over what one $\mathrm{HEI}$ employee described as the UK government's 'attitude' towards immigrants:

I got some Chinese face or something, that's the only thing I'm concerned about. I'm not considered about a job or anything. If I can't get job here I can move back to China or to another country, I'm not worried. But I consider how the government considers immigrants. I don't want them to see immigrants to be, like, people who take the jobs [from UK citizens].

In this excerpt, the interviewee combined concern for his personal well-being with a degree of pragmatism, being well aware of the marketability of his skills. Other participants, whilst not mentioning any sense of a physical threat, had also experienced a degree of hostility from elements of the population within their locality. One participant, a South American academic (interviewed in Autumn 
2010), spoke of how the 'social climate [had] changed' in the run-up to the May 2010 general election:

[W]e did have some small incidents in the local shops with one of the local shop-owners talking about being swamped with immigrants and I said 'I'm one of them and I'm thinking of not buying from your shop again', and went off...

Such views stress that, even without a BRP, exclusion can be an issue for skilled and educated migrants. Documents such as the BRP can remind the holder that they are 'different'. At the same time, many non-EEA interviewees understood the BRP's importance in enabling the UK authorities to distinguish between legal and undocumented migrants. Indeed, they believed that a positive aspect of the BRP was that it provided a clear and visible means by which this could be done on an everyday basis.

By contrast, the advocacy groups were more critical of the motivations behind the BRPs. A senior manager at a national migration advocacy group stated that the permits were a political tool, a 'control mechanism', supporting a wider 'enforcement agenda': '[l]t is essentially about having [foreign nationals] in a place where they can be grabbed hold of pretty quickly if they step out of line'. They believed that this approach by the UK authorities was, moreover, misleading, as it 'implies [...] a promise to the public that control can be administered in this way' (officer, national migration advocacy group). In their opinion, this was not possible. As a result, this attempt to 'manage' non-EEA migrants could undermine the UK government. In these circumstances, they reiterated the view that BRPs had to apply to all UK residents, 'or none' (manager, regional migration advocacy group). This concern was in part due to a lack of trust in the ability of government departments-in particular, the Home Office-to keep personal data secure. One interviewee, based at a regional migration advocacy group, recalled UK Home Office operations being declared 'not fit for purpose' (BBC News 2006) and that another government department had lost 25 million child-benefit records. ${ }^{12}$ Nevertheless, this anxiety at the government's data handling procedures was not generally voiced by the foreign nationals interviewed. In fact, the majority did not question the UK government's capacity to look after their personal data. For example, HEl staff from the Far East and South Asia, respectively, stated:

\footnotetext{
I trust this government, I trust the organisations to keep the confidential things confidential and be careful with them.

I think I'm happy to trust the government because simply if something goes wrong, then I
can shout ... there will be people to hear.
}

These representations, combining a general confidence of interviewees in the UK 'government' per se (if not in individual departments) with a belief in their ability to manage any problems that may arise, typified the self-assurance and pragmatic approach to everyday life in the UK taken by a number of non-EAA migrants. Participants were, in general, attracted to the UK for reasons of 
personal and professional development. At the same time, they were aware that they had other options. This view was summarised by a South Asian HEl employee:

I just want to work for a good company and do some good work with good pay. I won't be chasing lots of people to make changes in this current system. If you like it you can have me, if not, l'll go somewhere else, that's the way I see it.

Other non-EEA migrants were drawn by the perceived freedom enjoyed by UK residents, with a South Asian HEl employee stating 'I can do what I want as long as it's not illegal'. Finally, the foreign nationals interviewed-perhaps due to being employed or enrolled as students in key economic sectors such as engineering, science, business and information technology_showed strong awareness of their skill set and their attractiveness to employers across the globe. In the words of one HEl employee, they were 'culturally adaptable'. A number of interviewees had worked overseas-in countries as diverse as South Korea, Singapore, Australia and Germany_prior to arriving in the UK, and were perfectly prepared to travel again. As a HEl employee from South Asia stated: 'If people think that you have something to offer [...] you have opportunities in other places/countries'. At the same time, there were some HEI staff who felt that their future lay in the UK for personal or career reasons and they were keen to be permitted to remain in the country. For these individuals, enrolment for a BRP was a necessity, if at times inconvenient.

Our data reveal that the highly skilled and educated non-EEA migrants interviewed were actively making strategic choices about where to live, study and work. As part of this process, they were aware that they needed to deal with immigration policies, notwithstanding the challenges they incurred. The enrolment of parts of their biometric data, to be stored indefinitely (in most cases) on government databases, and the requirement for an increasing number of foreign nationals to possess a BRP were just a few aspects of these challenges, indicative of the additional surveillance which national governments have increasingly imposed on migrant communities (Amoore 2006; Diminescu 2008; Lyon 2007a). Nevertheless, foreign nationals' experiences of dealing with the BRP suggest that these groups managed to negotiate their way around any issues and problems they encountered. Yet, this was not without the occasional questioning of the need for a BRP, and the encountering of difficulties during the actual process of acquiring the card.

\section{Discussion and Conclusion}

This paper adds to debates on the surveillance of migrants, and its impact on identity, belonging and everyday life, by investigating the effect of the BRP on non-EEA students and skilled workers within HEls during a time of considerable policy change in the UK. Although the size of the interview sample was admittedly small, the aim of this paper has been to highlight areas for further debate. We draw attention to two findings: the significance of the BRP process as 
a means of surveillance and control of foreign nationals across, and within, national boundaries; and the pragmatism of migrants in negotiating the impacts of surveillance on belonging and identity in everyday life.

The BRP, introduced via EC Regulations to enable EU states to 'manage' migration, arguably at the same time serves to remind non-EEA migrant workers and students that they are temporary foreigners within these jurisdictions. Our investigation has demonstrated that the BRP has the effect of making a number of non-EEA migrants feel unwelcome within the UK and has reinforced feelings of 'difference'. In particular, some interviewees were concerned that they were being 'singled out' for enrolment to the BRP, causing them to consider their current status and future prospects in the UK. Moreover, the BRP, and the biometric data collected, are notable-not just as forms of embodied surveillance conducted at the scale of the individual migrant (Dunn 2010) —but also as a means for the state to potentially control migrants beyond official borders. Increasingly, non-EEA migrants to the UK are being required to supply their biometric data at various sites: within their home country (prior to departure), at UK airports (on arrival), and inside the UK (as part of the BRP enrolment process). These operations form part of the 'securitisation' of the migrant body, depicting it as a threat to the state (Amoore 2006; Broeders 2007; Wilson and Weber 2008; Zureik and Salter 2005). However, in spite of this 'social sorting' (Lyon 2007b), our study yielded only a few examples of foreign nationals feeling criminalised by the capture of their biometric data. Yet, the BRP, through this extraction of biometric data at various points in the migrant's journey, has arguably transformed the geographies of UK government surveillance, redefining the national border as a series of sites both extending beyond, and reaching within, national boundaries. Externally, the migrant gives his or her biometric data prior to, and often at, arrival in the UK. Internally, the migrant is often required to produce the card long after enrolment, as they negotiate various internal barriers during the course of everyday life-for example, opening a bank account, hiring a car or applying for a temporary job.

Consequently, the BRP can be conceptualised as an important aspect of migrant surveillance in the UK. Given its roll-out across a number of migrant groups, there is a need to engage with how the card impacts on migrants and the ways in which the UKBA can make the application and acquisition process more streamlined. For example, reforms could be made to existing procedures that involve the UKBA handling applications and the DVLA separately processing and issuing the cards. In addition, given the fact that the great majority of non-EEA migrants are now required to apply for the card, it would be prudent for the UK government to consider reducing the number of sites at which migrants are obliged to register their biometric data during the initial application for, and renewal of, their visas.

Our investigation also found that, although a number of foreign nationals questioned the increased surveillance they were subject to, many also accepted it as part of a quid pro quo in exchange for the opportunities afforded to them for professional development in the UK. As a result, it is important to pay attention to the ways in which migrants deal with, and rationalise, security and surveillance in 
order to manage their everyday lives in the UK. Our interviewees illustrated that surveillance in the form of BRPs can, on the one hand, be problematic in symbolic and material ways, potentially accentuating perceptions of difference. Yet, on the other hand, the BRP has allowed migrants to prove their legality and identity in particular spaces and, in some instances, take advantage of the flexibilities within the system to move between employers. Although foreign nationals recognised that the issuing of the BRP solely to non-EEA migrants could result in discriminatory treatment, they were pragmatic about the surveillance involved and its existence as a corollary to mobility across the globalised economy.

Our research suggests that we need to recognise that the impacts of surveillance on migrant populations are not necessarily negative but are often nuanced, messy and complex. One way of analysing such impacts is through the voices and opinions of those affected. In this paper, we have focused on how migrants perceive surveillance in detailed ways. Surveillance can, and often is, seen as problematic, resulting in migrants feeling singled out, discriminated against and 'different'. Yet, migrants can also be seen as actively managing surveillance as they go about their daily lives, resulting in subtle, situated and flexible responses to this form of monitoring.

\section{Notes}

[1] The European Economic Area (EEA) comprises the 27 countries of the European Union, plus Iceland, Liechtenstein and Norway.

[2] An interview at a UKBA Public Enquiry Office revealed that the biometric data taken from foreign nationals on enrolment for BRPs are, in effect, kept indefinitely.

[3] The UKBA is an agency of the Home Office. It was formed on 1 April 2008 following a merger of the Border and Immigration Agency, UKvisas and some functions of HM Revenue and Customs.

[4] These fees increased significantly on 6 April 2011. For further details, and a link to existing and proposed fees, see: http://www.ukba.homeoffice.gov.uk/sitecontent/newsarticles/2011/february/ 66-propose-fee-increases, last accessed 15 March 2011.

[5] UKBA interviewee, October 2010.

[6] The requirement for the capture of fingerprints from six years of age is included in EC Regulation 380/2008. This Regulation states the number of fingerprints (two) required to be taken by member-states. The UK government elected to go beyond this by capturing all ten fingerprints (Liberty 2010).

[7] UKBA interviewee, October 2010.

[8] UKBA interviewee, May 2010. The DVLA is an executive agency of the UK Department for Transport. It holds records on 43 million drivers and 36 million licensed vehicles (DVLA 2010).

[9] Interviewee, HE industry body, September 2010. 
[10] One student reported that his card was not recognised when he was asked to provide proof of identification to buy alcohol at the local supermarket; another interviewee stated that his card had caused the authorities some confusion when he produced it in another EU country. Although the BRP cannot be used in place of a passport or a travel document, foreign nationals are required to take it with them when they go abroad 'while [they] have permission to stay in the UK' (UKBA 2010b).

[11] This is in spite of assertion by the UKBA that a BRP can help to 'make life easier for the BRP holder' (Home Office 2010: 12).

[12] The department in question was Her Majesty's Revenue and Customs (HMRC). This data loss was revealed in November 2007-see http://news.bbc.co.uk/1/hi/uk_politics/7103566.stm, last accessed 15 March 2011.

\section{References}

Abbas, T. (2007) 'Muslim minorities in Britain: integration, multiculturalism and radicalism in the post-7/7 period', Journal of Intercultural Studies, 28(3): 287300.

Amoore, L. (2006) 'Biometric borders: governing mobilities in the war on terror', Political Geography, 25(3): 336-51.

Bach, S. (2010) 'Managed migration? Nurse recruitment and the consequences of state policy', Industrial Relations Journal, 41(3): 249-66.

BBC News (2006) 'Immigration system unfit-Reid', BBC News, 23 May. http://news.bbc.co.uk/1/hi/uk_politics/5007148.stm, last accessed 15 March 2011.

Beaverstock, J. (2005) 'Transnational elites in the city: British highly-skilled intercompany transferees in New York City's financial district', Journal of Ethnic and Migration Studies, 31(2): 245-68.

Beynon-Davies, P. (2006) 'Personal identity management in the information polity: the case of the UK national identity card', Information Polity, 11(1): 319.

Beynon-Davies, P. (2007) 'Personal identity management and electronic government: the case of the national identity card in the UK', Journal of Enterprise Information Management, 20(3): 244-70.

Beynon-Davies, P. (2010) 'Personal identity management as a socio-technical network', Technology Analysis and Strategic Management, 22(4): 463-78.

Broeders, D. (2007) 'The new digital borders of Europe: EU databases and the surveillance of irregular migrants', International Sociology, 22(1): 71-92.

Burdsey, D. (2006) "'If I ever play football, Dad, can I play for England or India?": British Asians, sport and diasporic national identities, Sociology, 40(1): 11-28.

Casciani, D. (2008) 'Analysis: the first ID cards', BBC News, 25 September. http://news.bbc.co.uk/1/hi/uk_politics/7634744.stm, last accessed 15 March 2011.

Conservative Party (2010) Invitation to Join The Government of Britain. London: Conservative Party. 
Delanty, G. (2008) 'Fear of others: social exclusion and the European crisis of solidarity', Social Policy and Administration, 42(6): 676-90.

Diminescu, D. (2008) 'The connected migrant: an epistemological manifesto', Social Science Information, 47(4): 565-79.

Doomernik, J., Koslowski, R. and Thranhardt, D. (2009) The Battle for the Brains: Why Immigration Policy is Not Enough to Attract the Highly Skilled. Washington DC: German Marshall Fund of the United States, Brussels Forum Paper Series.

Dunn, K. (2010) 'Embodied transnationalism: bodies in transnational spaces', Population, Space and Place, 16(1): 1-9.

DVLA (2010) DVLA Information Charter. Swansea: DVLA.

Favell, A., Feldblum, M. and Smith, M. (2009) 'The human face of global mobility: a research agenda', Society, 44(2): 15-25.

Finch, T. and Mulley, S. (2009) 'Navigating the migration debate out of a dangerous cul-de-sac', Public Policy Research, 16(2): 120-6.

Findlay, A., King., Geddes, A., Smith, F., Stam, A., Dunne, M., Skeldon, R. and Ahrens, J. (2010) Motivations and Experiences of UK Students Studying Abroad. London: Department for Business, Innovation and Skills, BIS Research Paper No 8.

Flynn, D. (2005) 'New borders, new management: the dilemmas of modern immigration policies', Ethnic and Racial Studies, 28(3): 463-90.

Geddes, A. (2006) 'The politics of irregular migration, human trafficking and people smuggling in the United Kingdom', in Guild, E. and Minderhoud, P. (eds) Immigration and Criminal Law in the European Union. Leiden: Brill, 37186.

Hawthorne, L. (2008) The Growing Global Demand for Students as Skilled Migrants. Washington, DC: Migration Policy Institute.

Home Office (2008) The Economic Impact of Immigration. The Government Reply to the First Report from the House of Lords Committee on Economic Affairs. Session 2007-08. HL Paper 82, June, Cm 7414. London: The Stationery Office.

Home Office (2010) Impact Assessment of Biometric Residence Permits-Tiers 1 and 5 of Points-Based System. IA No: HO0019, 8 October. London: Home Office.

House of Commons (2009) Managing Migration: The Points-Based System. Thirteenth Report of Session 2008-09, Volume 1. London: HoC Home Affairs Committee.

House of Lords (2010) Debate, 8 November. Hansard. http://www.publications.parliament.uk/pa/ld201011/ldhansrd/text/101108gc0001.htm, last accessed 15 March 2011.

Hussain, Y. and Bagguley, P. (2005) 'Citizenship, ethnicity and identity: British Pakistanis after the 2001 "riots"', Sociology, 39(3): 407-25.

Joinson, A., Paine, C., Buchanan, T. and Reips, U.-D. (2006) 'Watching me, watching you: privacy attitudes and reactions to identity card implementation scenarios in the United Kingdom', Journal of Information Science, 32(4): 33443. 
Kim, T. (2007) 'Transnational academic mobility in a global knowledge economy', in Epstein, D., Boden, R., Deem, R., Rizvi, F. and Wright, S. (eds) Geographies of Knowledge, Geometries of Power: Framing and the Future of Higher Education. Abingdon: Routledge, PAGE NOS?.

Koser, K. and Salt, J. (1997) 'The geography of highly skilled international migration', International Journal of Population Geography, 3(4): 285-303.

Ley, D. (2004) 'Transnational spaces and everyday life', Transactions of the Institute of British Geographers, 29(2): 151-64.

Ley, D. (2010) Millionaire Migrants: Trans-Pacific Life Lines. Chichester: John Wiley.

Liberal Democrat Party (2010) Manifesto 2010. London: Liberal Democrats.

Liberty (2010) Liberty's Second Reading Briefing on the Identity Documents Bill in the House of Lords. London: PUBLISHER?.

Lyon, D. (2007a) 'National ID cards: crime-control, citizenship and social sorting', Policing: A Journal of Policy and Practice, 1(1): 111-18.

Lyon, D. (2007b) 'Surveillance, security and social sorting: emerging research priorities', International Criminal Justice Review, 17(3): 161-70.

Nagel, C. (2002) 'Constructing difference and sameness: the politics of assimilation in London's Arab communities', Ethnic and Racial Studies, 25(2): 258-87.

Phillips, D. (2006) 'Parallel lives? Challenging discourses of British Muslim selfsegregation', Environment and Planning D: Society and Space, 24(1): 25-40.

Phillips, D. (2010) 'Minority ethnic segregation, integration and citizenship: a European perspective', Journal of Ethnic and Migration Studies, 36(2): 20925.

Robinson, D. (2010) 'Migration in the UK: moving beyond numbers', People, Place and Policy Online, 4(1):14-18.

Spencer, S. (ed.) (2003) The Politics of Migration. Oxford: Blackwell.

UCAS (2010) Passport and visa requirements, UCAS. http://www.ucas.com/students/wheretostart/nonukstudents/documents, last accessed 15 March 2011.

UKBA (2010a) The Student Immigration System: A Consultation. London: UKBA.

UKBA (2010b) The Points-Based System: Comparisons with Previous Immigration Work Routes. http://www.ukba.homeoffice.gov.uk/workingintheuk/comparisons/, last accessed 15 March 2011.

UKBA (2010c) Do I Need a Biometric Residence Permit? http://www.ukba.homeoffice.gov.uk/while-in-uk/do-i-need-brp/\#, last accessed 15 March 2011.

Van Houtum, H. and Pijpers, R. (2007) 'The European Union as a gated community: the two faced border and immigration regime of the EU', Antipode, 39(2): 291-309.

Whitley, E. and Hosein, I. (2008) 'Doing the politics of technological decisionmaking: due process and the debate about identity cards in the UK', European Journal of Information Systems, 17(6): 668-77. 
Whitley, E., Hosein, I., Angell, I. and Davies, S. (2007) 'Reflections on the academic policy analysis process and the UK identity cards scheme', The Information Society, 23(1): 51-8.

Wilson, D. and Weber, L. (2008) 'Surveillance, risk and preemption on the Australian Border', Surveillance and Society, 5(2): 124-41.

Zureik, E. and Hindle, K. (2004) 'Governance, security and technology: the case of biometrics', Studies in Political Economy, 73: 113-37.

Zureik, E. and Salter, M. (2005) 'Who and what goes where? global policing and surveillance', in Salter, M. and Zureik, E. (eds) Global Surveillance: Borders, Security, Identity. Cullumpton: Willan Publishing, 1-10. 